\title{
Transnational business human rights regulations and their effects upon human rights protection
}

\author{
Sumi Dhanarajan
}

Contemporary corporate-related human rights abuses are often attributed to the processes of neo-liberal globalisation. ${ }^{1}$ Pressures upon nations to compete in the global marketplace, upon suppliers to produce ever-cheaper and everfaster, upon workers to accept more precarious terms of employment and upon communities to give up land and natural resources, all in the pursuit of economic growth have unveiled examples of the darker side of business operations within the global economy. Whereas this side was more hidden and less susceptible to resistance in a different era, transnational activism in this age - with the aid of new forms of communication technology and media - has enabled greater public awareness of this miscreant behaviour and the ensuing injustices.

Consequently, demands have been placed upon governance systems to provide the necessary controls and protections to allay the growing problem of human rights abuses occurring as a result of business activities. Transnational business human rights regulatory regimes ('TBHRs') have emerged as a means of managing the human rights impact of global corporate activity. This form of regulatory governance is often described as a necessary 'gap-filler' (Ruggie 2013). Promoted as an interim solution to the problem of unfettered adverse business human rights impact in the apparent absence of adequate state-based measures, it is assumed that TBHRs fill a regulatory void.

1 I define neo-liberal globalisation as globalisation deriving from the "Washington Consensus' that promotes trade and financial liberalisation, privatisation and deregulation, openness to foreign direct investment, a competitive exchange rate, fiscal discipline, lower taxes and small government. Transnational business governance is associated with this agenda by enabling it through self-regulation and minimal state intervention (Tabb 2005). The typologies of globalisation and the definition of neo-liberal globalisation in the context of human rights are discussed extensively in O’Connell (2007). 
This assumption is somewhat misleading. In fact, TBHRs emerge into a space already occupied by state-based law and institutions, albeit that these may be currently weak or inefficient, or simply untested. Understood in this way, the emergence of TBHRs raises questions about the effects and implications of the interactions these regulatory instruments have with extant rights-protecting laws. Yet the nature and outcomes of the interactions between TBHRs and law remain understudied even though they may prove to be a critical indicator of how human rights discourse evolves in 'globalised' States in which nonstate actors play a prominent role in formulating norms and implementing regulation relating to human rights.

\section{The emergence of transnational business human rights regulation}

TBHRs - a form of transnational business governance or transnational private regulation - have emerged as a means of managing the unfettered adverse human rights impact of global corporate activity, as well as a way to secure businesses' social license to operate in the globalised context. Their application reflects a broader trend towards normalising private rule-making across various regulatory spheres. In the absence of an 'overarching global political regime' (Haufler 2000) to manage complex issues such as business-related human rights abuses, the shift away from state-based rule-making is seen as inevitable (Barendrecht 2013). The 'regulatory fracture' of the global economy wherein industries involved in highly globalised systems of production are beyond the state's current regulatory reach contribute to this perception (de Sousa Santos and Rodriguez-Garavito 2005).

The emergence of TBHRs thus reflects three drivers. First, a perception that states either lack the institutional capabilities and capacities to address the problem satisfactorily or, are committed to neo-liberal deregulatory policies that demand non-state regulatory instruments (Bartley 2003). Second, the corporate imperative to respond efficiently with risk management tools that can either quell the ensuing reputational damage or ensure the viability of business operations in the face of social resistance, or to deflect state-based regulation. Third, pressure from transnational advocacy movements to seek out means of holding corporations to account for human rights violations relating to their operations.

We can observe these drivers playing out in many developing, globalising States where human rights abuses resulting from business activity are prevalent. Key industries harbour systemic human rights challenges, for example, poor working conditions in low-cost manufacturing, or disputes over natural resources and land resulting in violence, displacements and violations of civil, cultural, economic, political and social rights. Existing legal provisions either fail to comprehensively cover the facts of the claim or are weakly enforced. In these situations, the business-operating environment can permit companies to 
be less responsive to human rights issues. Further, victims of human rights face significant barriers to accessing legal remedies to either prevent further harm or to gain compensation or reparation for harm caused.

In the face of these challenges, transnational advocacy groups have supported local civil society in raising awareness at the domestic and global level, calling for increased corporate accountability. Under this spotlight, multinational corporations as well as larger domestic companies implicated in these rights abuses have, in some instances, sought out TBHRs as either a superficial means of cover, or in a genuine effort to understand and address the problems before they begin to pose material risks to the business. Likewise, communities, in tandem with civil society organisations, have also sometimes looked to TBHRs as a more accessible means of seeking remedy.

TBHRs take various forms: self-regulating instruments such as corporate codes of conduct that are designed and implemented by companies themselves to ensure their own as well as their supply-chain partners' compliance with human rights standards; regulatory regimes implemented through multistakeholder initiatives involving companies and other actors such as nongovernmental organisations (examples include the Roundtable on Sustainable Palm Oil, the Ethical Trading Initiative or the Voluntary Principles on Security and Human Rights); or compliance mechanisms implemented by international or regional financial institutions which build in social and environmental impact assessment requirements into approval processes for loans and partnerships, such as the Compliance Advisory Ombudsman for the International Finance Corporation. Ever-new species of TBHRs proliferate to address the variety of issues and dynamics in the business and human rights space.

Proponents of this trend towards transnational private regulation believe that these mechanisms bring the benefits of plurality: different types of rulemaking and the increase in rule-making capacity can mean thicker protection for human rights (Barendrecht et al. 2013). Further, TBHRs are seen to be more efficient and more flexible than state-based regulation, the latter being unduly constraining in achieving rights-based solutions when the abuses in question involve complex situations (Rees 2012). An often quoted example is that of child labour, where mediation-based mechanisms may achieve better outcomes by taking into account the reasons why the child is working and finding appropriate solutions in ways that litigation may not.

Those more circumspect about TBHRs question whether these mechanisms are accountable to victims, whether the voluntary nature of some of the mechanisms prevents enforceability, and whether the imbalances of power between the victims and the companies distort the fairness of the processes (Deva 2012). Skeptics question the effects of TBHRs upon social change asking, for example, if they encourage States to further renege on their duties to protect human rights against corporate abuses (Perez 2011). 
In any case, the place of TBHRs within the business and human rights landscape is quite secure. Indeed the UN Guiding Principles on Business and Human Rights, endorsed by the UN Human Rights Council in 2011, support the use of TBHRs as a means to deliver due diligence as well as access to remedy, both being obligations associated with the Principles' requirements of meeting the corporate responsibility to respect human rights and of ensuring greater access by victims to effective grievance mechanisms. ${ }^{2}$

\section{For better or worse?}

The problem, however, is that analysis of TBHRs is focused mainly upon investigating whether they are in and of themselves effective regulatory instruments (that is, assessing the efficiency of these instruments in ensuring compliance or legitimacy) or whether they provide adequate access to remedies to victims. In both regards, they are often juxtaposed against state-based laws or legal institutions for rights-protection, assessed as either better than, or worse than the latter. There are, however, shortcomings in conceptualising TBHRs as part of a wider human rights ecosystem whereby their introduction, as a new species of regulatory regime, may effect the nature and functioning of other existing regimes as well as that of the ecosystem as a whole.

In effect, TBHRs pluralise human rights protection by introducing into a traditionally public terrain alternative private fora for determining applicable human rights norms and standards and for adjudicating or mediating disputes arising in connection with corporate-related rights abuses. Not examining their pluralising effects precludes an understanding of whether the systemic impact of having TBHRs is net-beneficial or net-detrimental to protection against or remedy of corporate-related human rights abuses. Ignoring the question of how TBHRs interact with other rights-related regimes makes it difficult to ascertain whether they actually enhance, complement, support, marginalise or undermine the latter, or importantly, to assess the implications of any of these possible relational effects upon rights discourse and praxis.

\section{TBHRs, the role of law and the meaning of human rights}

The role of law in protecting against and remedying corporate-related human rights abuses is in a state of flux. As suggested earlier, TBHRs are most often justified on the basis that the law has failed. The relatively slow evolution of law to address business and human rights can be, in part, traced back to normative and doctrinal barriers to finding non-state actors responsible for human rights violations. Consequently, most legal challenges have been based

2 Guiding Principles on Business and Human Rights: Implementing the United Nations "Protect, Respect and Remedy" Framework, U.N. Doc. A/HRC/17/31 (Mar. 21, 2011) (by Professor John Ruggie) [hereinafter 'The Guiding Principles']. 
on civil, criminal law, or administrative law, ${ }^{3}$ rather than claims for breaches of fundamental freedoms or rights protected under national constitutions or international human rights law. In pursuing such cases, whereas the harm may be 'named' as human rights abuse, the 'claiming' process in the dispute usually veers aware from addressing it as such ${ }^{4}$ (Felstiner et al. 1980). For example, in a tort claim, the injury may be presented as trespass to the person or the claim framed as negligence. According to McCorquodale, one consequence of this phenomenon may be that 'we lose the powerful, challenging idea of human rights' when legal challenges are framed without human rights-related legislation or international conventions. ${ }^{5}$

Further, in making these claims numerous doctrinal and evidential obstacles present. There are also the overwhelming practical barriers to accessing the judicial system ranging from lack of financial resources, to simply lacking the capabilities to engage the legal system (Taylor et al. 2009). Having said this, there is an 'expanding web of liability' (Thompson, Ramasastry and Taylor (2009) cited by Zerk 2014, 14) for corporate abuses of human rights and there continue to be efforts to test and engage the law's muscle in addressing these contemporary human rights challenges presented by corporate-related harms. At the international level, the current process in the UN Human Rights Council to explore an international treaty represents one such effort. As the law is evolving within a regulatory space occupied - indeed prominently so - by TBHRs, it is important to think about what influence or impact these may have upon its development. As a human rights advocate, my particular interest is in how TBHRs affect the development of law as a counter-hegemonic force.

There are a number of ways in which TBHRs could affect the role of law - and the meaning of human rights - through their presence and interactions with it. For example, where the law provides few reference points for their decision-making, judges may reference or even show deference to the processes and outcomes of alternative dispute resolution proceedings provided by the TBHR where these are seen as relevant to a case before them ${ }^{6}$ and especially

3 For a comprehensive account of these, see Zerk (2014) and Skinner, McCorquodale, and De Schutter (2014).

4 An exception to this may be the Alien Tort Claims Act cases where the US district courts have original jurisdiction of any civil action by an alien for a tort where that tort is committed in violation of the law of nations or a treaty of the United States.

5 Presentation by Professor Robert McCorquodale, Director of the British Institute for International and Comparative Law at a Seminar on Transnational Corporate Human Rights Abuses: Delivering Access to Justice, London, UK, 17 July 2014.

6 Known as 'legal endogeneity', the concept developed by Lauren Edelman and her collaborators (Edelman et al. 2011) suggests that law acquires meaning from (and in this way becomes endogenous to) the social arenas it seeks to regulate. Her research considered how organisations that actively participate in the construction of the meaning of compliance with the law generate "ideologies of rationality" which in 
where the norms and standards set by TBHRs become ubiquitous with the site or type of grievance. ${ }^{7}$

TBHRs may influence rights mobilisation; for example, activists may disengage with the legal regime, preferring recourse to TBHR norms and processes as a way of confronting or resolving grievances involving affronts to human dignity or, alternatively, may be encouraged to pursue litigation having had negative experiences with TBHRs. In framing a grievance, activists may choose to amalgamate norms from both TBHRs as well as the law so as to generate hybrid understandings of rights in their rights mobilisation. TBHRs may influence rights consciousness, that is the way individuals and communities think about and act towards human rights, affecting the way they understand, engage with or use the law to protect their rights (Engel 2012; McCann 2012). TBHRs may hamper the transformative or counter-hegemonic potential of the law by shifting the articulation of the scope of rights, their protection and their remedy from a public into a private space. This could 'create an illusion of accountability and thus reduce the demand for actual change' (Chesterman 2011,63 ) that may arguably be better secured through litigation. Alternatively, they may actually encourage the transformative potential by offering new visions of how human rights could be reflected in law.

The point is little light is shed on the interactions between TBHRs and legal regimes. Whilst policy-makers actively promote TBHRs in line with a paradigmatic shift from government to governance, scant attention is being paid to the systemic effects and implications relating to their implementation upon the role of law and the meaning of human rights in contemporary practice. Deepening our understanding of these would be an important gauge of the future of human rights protection in our globalised world.

\section{Bibliography}

Barendrecht M., D. Raic and S. Muller (2012) Rulejungling: When lawmaking goes private, international and informal. The HIIL Trend Report, available at http://www.hiil.org/publication/trend-report-rulejungling (accessed 30 Sept. 2015).

Bartley, T. (2003) 'Certifying forests and factories: states, social movements and the rise of private regulation in the apparel and forest product fields', Politics and Society 31, pp. 433-64.

turn, legitimate and reinforce particular compliance strategies in the social field, something to which courts and other legal actors may well respond.

7 An example of this is perhaps the norm of free, prior and informed consent that has been developed predominantly within TBHRs, and may have some influence over how judges interpret the constitutional rights elements in land disputes over mining or agricultural concessions. 
Chesterman, S. (2011) 'Laws, standards and voluntary guidelines', in G. Nystuen, A. Follesdal and O. Mestad (eds.), Human Rights, Corporate Complicity and Disinvestment (Cambridge: Cambridge University Press).

de Sousa Santos, B. and C. A. Rodriguez-Garavito (2005) 'Law, politics and the subaltern in counter-hegemonic globalisation', in B. de Sousa Santos and C. A. Rodriguez-Garavito (eds.), Law and Globalisation From Below: Towards a Cosmopolitan Legality (Cambridge: Cambridge University Press).

Deva, S. (2012) Regulating Corporate Human Rights Violations (Abingdon: Routledge).

Eberlein, B., K. W. Abbott, J. Black, E. Meidinger and S. Wood (2013) Transnational Business Governance Interactions: Conceptualisation and Framework for Analysis, available at http://digitalcommons.osgoode.yorku. ca/scholarly_works/3 (accessed 30 Sept. 2015).

Edelman, L.B., L. H. Krieger, S. R. Eliason, C. R. Albiston and V. Mellema (2011) 'When organizations rule: judicial deference to institutionalised employment structures', American Journal of Sociology 117 (3), pp. 888-954.

Engel, D. M. (2012) 'Vertical and horizontal perspectives on rights consciousness', Indiana Journal of Global Legal Studies 19 (2), pp. 423-55.

Felstiner, W., R. Abel and A. Sarat (1980/81) 'The emergence and transformation of disputes: naming, blaming and claiming', Law \& Society Review 15 (3/4), p. 631.

Haufler, V. (2000) 'Private sector international regimes' in R. Higgot, G. Underhill and A. Bieler (eds.), Non-state Actors and Authority in the Global System (London: Routledge).

Levy, D. L. and R. Kaplan (2008) 'Corporate social responsibility and theories of global governance: strategic contestation in global issue arenas', in A. Crane, A. McWilliams, D. Matten and J. Moon (eds.), Oxford Handbook of Corporate Social Responsibility (Oxford: Oxford University Press).

McCann, M. (1994) Rights at Work: Pay Equity Reform and the Politics of Legal Mobilization (Chicago, IL: University of Chicago Press).

O'Connell, P. (2007) 'On reconciling irreconcilables: neo-liberal globalisation and human rights', Human Rights Law Review 7 (3), pp. 483-509.

Rees, C. (2012) Mediation in Business-related Human Rights Disputes: Objections, Opportunities and Challenges, Corporate Social Responsibility Initiative Working Paper No. 56 (JFK School of Government. Harvard University). 
Ruggie, J.G. (2013) Just Business: Multinational Corporations and Human Rights. Norton Global Ethics Series (New York: W.W. Norton \& Company).

Skinner, G., R. McCorquodale and O. De Schutter (2014) The Third Pillar: Access to Judicial Remedies for Human Rights Violations by Transnational Business (The International Corporate Accountability Roundtable (ICAR), CORE and The European Coalition for Corporate Justice (ECCJ)).

Tabb, W. K. (2005) Economic Governance in the Age of Globalization (New York: Columbia University Press.)

Taylor, M. B., R. C. Thompson and A. Ramasastry (2009) Overcoming Obstacles to Justice: Improving Access to Judicial Remedies for Business Involvement in Grave Human Rights Abuses (Amnesty International and FAFO).

Zerk, J. (2014) Corporate Liability for Gross Human Rights Abuses:

Towards a fairer and more effective system of domestic law remedies. A report prepared for the Office of the UN High Commissioner for Human Rights, available at http://www.ohchr.org/Documents/Issues/Business/ DomesticLawRemedies/StudyDomesticeLawRemedies.pdf (accessed 30 Sept. 2015). 